Hein von Westernhagen · Volkert Dethlefsen

Tim Bade $\cdot$ Werner Wosniok

\title{
Species assemblages of pelagic fish embryos in the southern North Sea between 1984 and 2000
}

Received: 8 February 2001 / Received in revised form: 5 November 2001 / Accepted: 6 November 2001 / Published online: 11 January 2002 C) Springer-Verlag and AWI 2002

\begin{abstract}
The occurrence and abundance of the pelagic eggs of southern North Sea spring-spawning fish were analysed between 1984 and 2000. Species number varied between six (1986) and 14 (1999) and was positively correlated with sea surface temperature. With one exception, dab eggs were always the most abundant and usually highly dominant. Ranking of species depended on temperature, but no significant differences in ranking between years was discernible. Although with the increase in temperature in the 1990s a change in species assemblage was evident [species belonging to the borealMediterranean (Lusitanian) group became more apparent in the species assemblage] this did not lead to an increased species diversity (Shannon Index) or a change in other community parameters. It appears that the recent developments regarding spawning stock biomass of commercial North Sea fish is reflected in the declining egg abundance of the respective commercial and larger species (i.e. cod, flounder, plaice) and an increase in abundance of the eggs of small species (i.e. long rough dab, rockling) over the years.
\end{abstract}

Keywords Dabs · Fish eggs $\cdot$ Pelagic fish $\cdot$ North Sea Species assemblage

Communicated by H.-D. Franke

H. von Westernhagen $(\varangle)$

Alfred-Wegener-Institut für Polar- und Meeresforschung,

Biologische Anstalt Helgoland, Columbusstrasse,

27568 Bremerhaven, Germany

e-mail: hwesternhagen@awi-bremerhaven.de

Tel.: +49-471-48311494, Fax: +49-471-48311425

V. Dethlefsen $\cdot$ T. Bade

Bundesforschungsanstalt für Fischerei,

Institut für Fischereiökologie, Deichstrasse 12,

27476 Cuxhaven, Germany

W. Wosniok

Institut für Statistik, Universität Bremen, Bibliothekstrasse 1, 28359 Bremen, Germany

\section{Introduction}

To date about 1.7 million species have been described, of which 250,000 are marine (UNEP 1995). Yet, although the land harbours more species than the sea, in terms of phylogenetical diversity the sea is more comprehensive. Of the 33 known animal phyla 32 are present in the sea and 15 are exclusively marine (Winston 1992; Norse 1993). Nevertheless, this marine biodiversity is today threatened by a number of factors of anthropogenic origin, these are: (1) increased human activity in coastal areas and the ensuing habitat destruction (i.e. coastal engineering, mariculture), (2) an increasing demand for marine products (i.e. over-fishing and the extinction of sensitive species), (3) industrial and domestic pollution (i.e. marine drilling and mining, land runoff), and (4) climate change and the ensuing loss of species.

Because of their wide geographic distribution, marine species were thought to be less susceptible to extinction than terrestrial ones. However, Vermeij (1993) was able to show that since the Pleistocene 15 marine species with a wide distribution have disappeared due to external influences. One factor that makes some species vulnerable to extinction is the fact that, although wide-ranging, they congregate for reproduction, thus exposing themselves to fishing or local pollution.

Local changes in marine biodiversity cannot easily be detected since the registration of species in the marine environment has to be achieved by diving or through the use of optical observation systems in the case of sessile species (i.e. coral reefs, benthic communities), or by the census of catches from usually very selective fishing gear (i.e. in dredges, trawls, traps, nets etc.). Any species evading these catching or registration devices eludes the attention of the investigator. Other species which are difficult to catch or are uncommon may only appear as rare guests in a census and it may take a long time before anybody will notice that this species may be endangered. Thus the detection of changes in biodiversity is also dependent on the degree of knowledge available for each respective area. 
For the North Sea and surrounding waters there are several time-series documenting past changes in community assemblages at different ecosystem levels. Hickel et al. (1968) and Radach and Bohle-Carbonell (1990) followed the seasonal phytoplankton succession in the southern North Sea and stated a dramatic increase in small flagellates in the phytoplankton community around Helgoland between 1962 and 1990. Fransz et al. (1991) were able to prove a similar development for the zooplankton of the southern North East Atlantic.

Similarly, changes in community structure over time have been demonstrated by Dörjes (1986) for the macrobenthic communities around Helgoland. During the period from 1930 to 1986, four echinoderms, two bivalves and two species of crustaceans have disappeared from the area. Kröncke (1992) who compared the macrobenthos community of the Dogger Bank between the years 1951 and 1985 discovered that species typical of a degraded habitat had increased, while other, more delicate, species such as Spisula solida and Mactra corallina had become extremely rare. For fish from the German Wadden Sea observations on the frequency of occurrence for certain non-target species in the by-catch of the shrimp fishery are available for the period between 1954 and 1981 and enable us to detect changes in species composition over time (Tiews 1990). Of the 25 species that had been routinely monitored, six had significantly increased, notably the sea snail (Liparis spp.), gobies (Pomatoschistus spp.), sole (Solea solea), eel (Anguilla anguilla), solenette (Buglossidium luteum) and gurnard Eutrigla gurnardus.

Aurich (1953) and Southward (1963) have also documented changes in species composition over time. Along with an increase in surface water temperature from the beginning of the twentieth century until 1945 (Cushing and Dickson 1976), changes in the occurrence of pelagic fish eggs in the southern North Sea (1926-1937) and species composition in bottom trawl catches off Plymouth between 1919-1922 and 1949-1952 were observed. For the North Sea ecosystem a typical phenomenon is the great number of seasonal guests, migrants or 'stragglers', species that do not live and reproduce in the North Sea, but are commonly found there on occasion (Lozán 1990; Berg et al. 1996).

Thus, observations usually need to cover a long period of time (i.e. several years) before lasting changes in biodiversity at a particular location can be identified.

In the present study, we refer to the occurrence of pelagic eggs of the winter/spring (February/March) spawning fish as a proxy for the occurrence, abundance and distribution of the respective adults. Relative occurrence and ranking of species will be used to detect shifts in species dominance and regional distribution. Additional information will be provided on the occurrence of eggs from summer spawners. However, due to the few cruises conducted in summer, only a limited comparison of the respective years is possible.

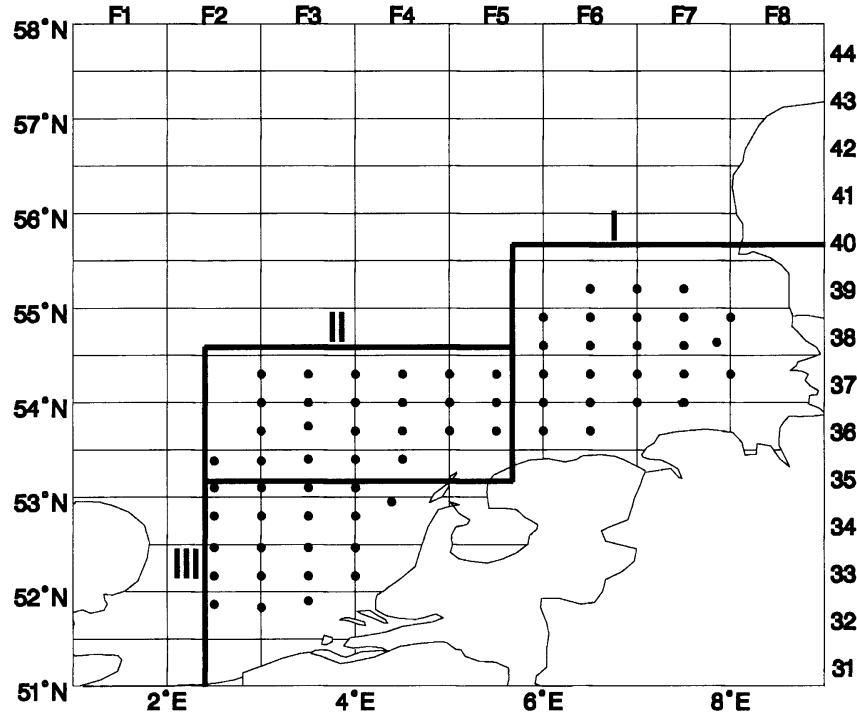

Fig. 1 Sampling area for pelagic fish eggs in the southern North Sea in the year 2000. Sub-areas I, II and III are indicated. Legends on top and on right side refer to ICES rectangles

\section{Materials and methods}

Sampling

Cruises have been conducted since 1984 in order to catch live pelagic fish eggs for biological monitoring purposes by determining the health of the embryos (Dethlefsen et al. 1996). Typically, the eggs of winter and spring spawners have been collected in February/ March. Summer cruises were conducted in June/July. Pelagic fish eggs were caught with a circular plankton net $(1 \mathrm{~m}$ in diameter; mesh size $300-500 \mu \mathrm{m}$ ) which was towed horizontally below the surface (2-5 m depth) for $10 \mathrm{~min}$. Immediately after capture, embryos were examined under a stereomicroscope in a cooled Petri dish and taxonomically classified. At each station up to 500 individual eggs were counted, yielding a minimum of roughly 20,000 eggs per cruise.

In the present paper we look at data on the occurrence of pelagic fish eggs from the southern North Sea in a rather confined area between $51^{\circ} 45^{\prime}-55^{\circ} 15^{\prime} \mathrm{N}$ and $03^{\circ} 00^{\prime}-08^{\circ} 00^{\prime} \mathrm{E}$ on a fixed station grid (Fig. 1). For comparison on a regional basis, the whole area was subdivided into three sectors, of which Area I was the German Bight proper (for the location of areas II and III see Fig. 1). For the calculation of diversity indices only data from 1986 onwards were used because, beginning in 1986, the whole species range present in the catches was determined routinely.

\section{Treatment of data}

Since the most complete data set is available for the winter/spring cruises in February/March, evaluation of data focused on springspawning species. However, for comparative reasons the results of summer cruises were also considered, given that they presented a totally different species assemblage and covered a larger number of species.

As a consequence of random sampling it was not possible to ensure that all sample sizes were equal. Since the number of species invariably increases with sample size and sampling effort (Preston 1948), we employed the 'rarefaction technique' (see Hurlbert 1971) for the determination of expected species numbers in order to standardise sample size and produce an unbiased estimate for species numbers.

Diversity was measured as species richness ( $n$ is number of species), as evenness or as dominance (relative abundance of 
Table 1 Table of indices used for the occurrence of pelagic fish eggs in the southern North Sea during the period 1986-2000. Bold figures are referred to in the text. tot total area. Data for 1908 taken from Ehrenbaum and Mielck (1910)

\begin{tabular}{|c|c|c|c|c|c|c|c|c|c|c|c|c|c|c|}
\hline \multirow[t]{2}{*}{ Index } & \multirow[t]{2}{*}{ Area } & \multicolumn{13}{|c|}{ Winter/summer } \\
\hline & & 1908 & 1986 & 1987 & 1990 & 1991 & 1992 & 1993 & 1995 & 1996 & 1997 & 1998 & 1999 & 2000 \\
\hline Berger-Parker Index & I & 0.82 & $0.59 / 0.52$ & $0.68 / 0.38$ & 0.66 & $0.46 / 0.43$ & $0.83 / 0.53$ & 0.86 & 0.79 & 0.43 & 0.69 & 0.7 & 0.79 & 0.72 \\
\hline Berger-Parker Index & II & 0.48 & 0.51 & $0.73 / 0.25$ & & $0.57 / 0.3$ & $0.73 / 0.34$ & 0.91 & 0.63 & 0.44 & 0.68 & 0.7 & 0.8 & 0.65 \\
\hline Berger-Parker Index & III & 0.57 & 0.45 & $0.6 / 0.47$ & & $0.35 / 0.26$ & $0.54 / 0.6$ & 0.71 & 0.57 & 0.36 & 0.62 & & 0.72 & 0.61 \\
\hline Berger-Parker Index & tot & 0.62 & 0.55 & $0.67 / 0.24$ & & $0.47 / 0.33$ & $0.75 / 0.4$ & 0.83 & 0.68 & 0.36 & 0.67 & & 0.78 & 0.66 \\
\hline Evenness & I & 0.38 & $0.63 / 0.63$ & $0.47 / 0.64$ & 0.48 & $0.68 / 0.66$ & $0.35 / 0.57$ & 0.33 & 0.35 & 0.53 & 0.5 & 0.45 & 0.37 & 0.43 \\
\hline Evenness & II & 0.59 & 0.74 & $0.47 / 0.82$ & & $0.64 / 0.8$ & $0.46 / 0.75$ & 0.19 & 0.56 & 0.64 & 0.51 & 0.46 & 0.34 & 0.47 \\
\hline Evenness & III & 0.64 & 0.66 & $0.62 / 0.6$ & & $0.67 / 0.67$ & $0.55 / 0.43$ & 0.47 & 0.54 & 0.81 & 0.56 & & 0.4 & 0.47 \\
\hline Evenness & tot & 0.54 & 0.68 & $0.47 / 0.77$ & & $0.62 / 0.76$ & $0.4 / 0.63$ & 0.3 & 0.47 & 0.61 & 0.51 & & 0.35 & 0.49 \\
\hline $\begin{array}{l}\text { Expected species } \\
\text { number }\end{array}$ & I & 5.98 & $5.99 / 11.55$ & $6.64 / 14.22$ & 10 & $7.17 / 14.98$ & 7.91/13.28 & 5.99 & 8.41 & 6.33 & 7.34 & 8.6 & 7.71 & 9.21 \\
\hline $\begin{array}{l}\text { Expected species } \\
\text { number }\end{array}$ & II & 9 & 6 & $7.17 / 12.8$ & & $6.69 / 13.1$ & $8.13 / 14.09$ & 7.91 & 9.01 & 7.52 & 8.32 & 10.14 & 9.22 & 9.97 \\
\hline $\begin{array}{l}\text { Expected species } \\
\text { number }\end{array}$ & III & 5.56 & 5 & $6.9 / 12.79$ & & 7.11/14.64 & 7.97/11.43 & 7.81 & 9.55 & 5.83 & 6.83 & & 10.61 & 9.73 \\
\hline $\begin{array}{l}\text { Expected species } \\
\text { number }\end{array}$ & tot & 9 & 6 & $8.62 / 15.99$ & & $8.9 / 18.3$ & $9.71 / 17.19$ & 9.34 & 11.47 & 8.72 & 9.48 & & 13.18 & 11.72 \\
\hline Index of dominance & I & 0.68 & $0.41 / 0.31$ & $0.5 / 0.24$ & 0.46 & $0.3 / 0.23$ & $0.7 / 0.32$ & 0.74 & 0.63 & 0.33 & 0.5 & 0.51 & 0.64 & 0.54 \\
\hline Index of dominance & II & 0.36 & 0.33 & $0.56 / 0.14$ & & $0.38 / 0.15$ & $0.55 / 0.18$ & 0.83 & 0.43 & 0.32 & 0.49 & 0.51 & 0.65 & 0.46 \\
\hline Index of dominance & III & 0.38 & 0.41 & $0.41 / 0.31$ & & $0.26 / 0.19$ & $0.36 / 0.44$ & 0.52 & 0.38 & 0.26 & 0.42 & & 0.53 & 0.44 \\
\hline Index of dominance & tot & 0.42 & 0.37 & $0.48 / \mathbf{0 . 1 5}$ & & $0.3 / \mathbf{0 . 1 6}$ & $0.57 / 0.24$ & 0.7 & 0.49 & 0.28 & 0.47 & & 0.62 & 0.46 \\
\hline Margalef's diversity & I & 0.67 & $0.51 / 1.32$ & $0.75 / 1.61$ & 1.15 & $0.74 / 1.83$ & $0.74 / 1.89$ & 0.52 & 1.13 & 1 & 0.82 & 1.04 & 0.94 & 1.11 \\
\hline Margalef's diversity & II & 1.19 & 0.55 & $0.77 / 1.56$ & & $0.66 / 1.57$ & $0.91 / 1.82$ & 0.96 & 0.99 & 0.84 & 0.85 & 1.21 & 1.26 & 1.17 \\
\hline Margalef's diversity & III & 0.72 & 0.47 & $0.66 / 1.42$ & & $0.9 / 1.9$ & $1.18 / 1.68$ & 0.87 & 1.18 & 0.57 & 0.87 & & 1.48 & 1.08 \\
\hline Margalef's diversity & tot & 0.91 & 0.48 & $0.87 / 1.51$ & & $0.88 / 1.82$ & $1.09 / 1.83$ & 0.95 & 1.14 & 0.91 & 0.85 & & 1.34 & 1.07 \\
\hline Shannon Index & I & 0.68 & $1.13 / 1.56$ & $0.97 / 1.77$ & 1.2 & $1.42 / 1.92$ & $0.73 / 1.62$ & 0.59 & 0.88 & 1.23 & 1.1 & 1.07 & 0.85 & 1.03 \\
\hline Shannon Index & II & 1.3 & 1.32 & $0.97 / 2.17$ & & $1.25 / 2.12$ & $1.02 / 2.03$ & 0.45 & 1.29 & 1.34 & 1.12 & 1.13 & 0.86 & 1.16 \\
\hline Shannon Index & III & 1.24 & 1.06 & $1.2 / 1.53$ & & $1.48 / 1.9$ & $1.32 / 1.15$ & 1.04 & 1.33 & 1.45 & 1.23 & & 1.06 & 1.12 \\
\hline Shannon Index & tot & 1.19 & 1.22 & $1.07 / 2.14$ & & $1.42 / 2.24$ & $1.01 / 1.83$ & 0.72 & 1.2 & 1.41 & 1.17 & & 0.96 & 1.21 \\
\hline
\end{tabular}

species), employing Shannon's diversity index which gives the proportional abundance of species (Pielou 1975). The index reaches its maximum value when all species are represented by the same number of individuals (Krebs 1999) but rarely surpasses 4.5 (Margalef 1972). Shannon's diversity index $\left(H^{\prime}\right)$ and Pielou's evenness index $\left(E^{\prime}\right)$ as well as Margalef's index were calculated for the different regions and different years (Table 1). The Shannon index was calculated using the formula:

$H^{\prime}=-\sum p_{i} \ln p_{i}$

where the quantity $p_{i}$ is the proportion of individuals found in the $i$ th species. In a sample the true value of $p_{i}$ is unknown but is estimated as $n_{i} / N$ (the maximum likelihood estimator, $N=$ total number of individuals and $n_{i}=$ the number of individuals in the $i$ th species; Pielou 1966).

Evenness was calculated as:

$E^{\prime}=H^{\prime} / H_{\max }=H^{\prime} / \ln S$

The maximum diversity $\left(H_{\max }\right)$ could be found in a situation where all species were equally abundant. The ratio of observed diversity to maximum diversity is taken as a measure of evenness $(E) . E$ is constrained between 0 and 1.0, with 1.0 representing a situation in which all species are equally abundant ( $S=$ number of species).

The Margalef index of diversity was calculated as:

$M=(S-1) / \ln N$

where $S=$ number of species and $N=$ total number of individuals. Species dominance was calculated employing Simpson's dominance index $D$, using the formula:

$D=\sum\left(p_{i}\right)^{2}\left(\right.$ with $\left.p_{i}=n_{i} / N\right)$

where $n_{i}=$ the number of individuals in the $i^{\text {th }}$ species, and $N=$ the total number of individuals. In addition the Berger-Parker Index was employed, which measures only the relative dominance $(\%)$ of the most abundant species. For both indices it is true that, with increasing diversity, dominance decreases.

Species abundance was ranked for the respective areas and compared using Spearman's and Kendall's rank correlation coefficient (Krebs 1999). A value of +1 indicates that two rankings are the same, and a value of -1 indicates that they disagree entirely.

\section{Results}

Species richness, abundance and assemblage

The number and relative abundance of species recorded during the spring cruises between 1984 and 2000 is depicted in Fig. 2. Since even a relatively small area such as the southern North Sea is not homogeneous in terms of its hydrography and has areas with high and low salinity and strong variations in temperature, results are not only presented for the overall area, but also for three sub-areas I, II and III (Table 1). In each winter (February/ March) in the overall area, species number varied between six (1986) and 15 (1999) and the maximum number in the sub-areas was 12 and 13. In summer only a limited cruise coverage was available for the whole period. Yet, even from the few data available, it was evident that species number in summer was elevated, reaching as many as 18 in summer 1991. It was also evident that species composition in summer was different 


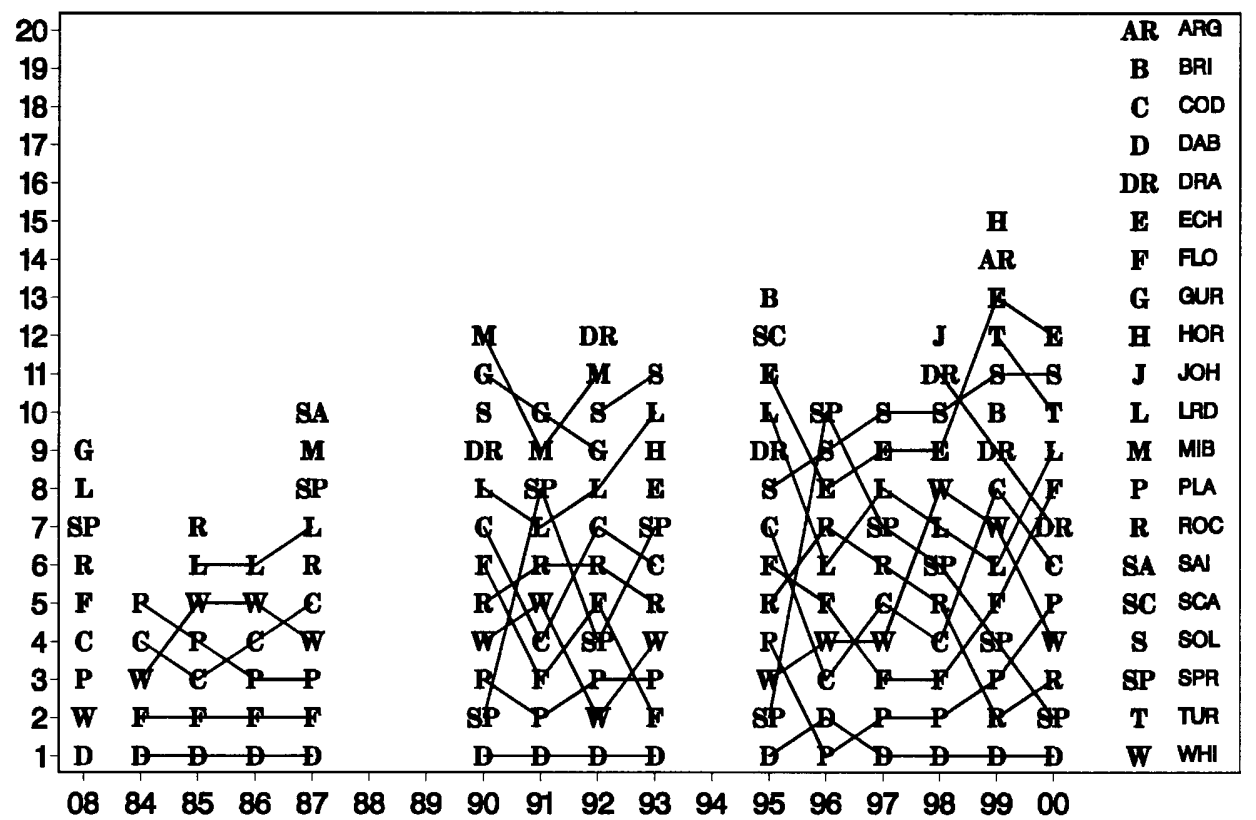

Fig. 2 Species and relative abundance (randomised ranks) of pelagic fish eggs between the years 1984 and 2000 in the southern North Sea. Note, in 1984 and 1985 only the indicated five (1984) and seven (1985) species have been recorded. 08 indicates data from Ehrenbaum and Mielck (1910). ARG Argentina silus (greater argentine), LRD Hippoglossoides platessoides (long rough dab), FLO Platichthys flesus (flounder), BRI Scophthalmus rhombus (brill), COD Gadus morhua (cod), DAB Limanda limanda (dab), GUR Eutrigla gurnardus (gurnard), SAI Gadus virens (saithe), SCA Arnoglossus laterna (scaldfish), DRA Callionymus lyra (dragonet), PLA Pleuronectes platessa (plaice), SOL Solea solea (sole), SPR Sprattus sprattus (sprat), ROC Onos spp. (rockling), TUR Psetta maxima (turbot), HOR Trachurus trachurus (horse mackerel), ECH Echiichthys vipera (lesser weever), WHI Merlangius merlangus (whiting), JOH Zeus faber (John dory), MIB Microchirus boscanion (no 'vernacular' name)

from the winter assemblage and that there was only a small overlap. This overlap consisted essentially of the four species dab (Limanda limanda), whiting (Merlangius merlangus), rockling (Onos spp.) and sprat (Sprattus sprattus).

During the whole period of investigation (i.e. winter/ spring plus summer) from 1986 until 2000, eggs of a total of 26 species were recorded. Over the years a general trend towards increasing species numbers for the southern North Sea could be detected during the spring cruises (from 10 in 1991 to 15 in 1999). No such trend can be seen in the summer data, due to insufficient coverage. When trying to correlate species number with sea surface temperature during February/March and June/July from the Helgoland Roads data $(R)$ and our own measurements during the respective cruises $\left(R_{\mathrm{I}}\right)$, a significant degree of correlation is apparent for both data sets $\left(R=0.883 ; R_{\mathrm{I}}=0.768\right)$ in all areas (Table 2; see also Fig. 2), providing proof of an increase of species number with increasing water temperature.

Due to the varying abundance of species, ranking was also highly influenced by temperature, as can be taken from the winter/spring samples depicted in Fig. 2. In
Table 2 Correlation (Pearson's coefficient of correlation) between temperature and 'expected number of species' for the occurrence of pelagic fish embryos in the southern North Sea 1986-2000. Cruise calculated from sea surface temperature (SST) during cruises; Helg mean SST data from February and March Helgoland Roads series

\begin{tabular}{lll}
\hline Area & $r$ Cruise & $r$ Helg \\
\hline I & 0.749 & 0.939 \\
II & 0.905 & 0.93 \\
III & 0.866 & 0.885 \\
All & 0.768 & 0.883 \\
\hline
\end{tabular}

winter, dab (Limanda limanda) eggs were usually the most abundant. For the overall area and area I only in 1996, plaice (Pleuronectes platessa) was more abundant, and also sprat in 1998 in area III. Both years were special regarding spring temperatures. 1996 was extremely cold with a mean sea surface temperature (SST) below $1{ }^{\circ} \mathrm{C}$ (with near shore station SST below $0^{\circ} \mathrm{C}$ ), a feature that favoured the winter-spawning plaice. The year 1998 was particularly warm, with a mean SST of more than $6^{\circ} \mathrm{C}$, favouring the Mediterranean species sprat (Clupea sprattus). Both species show an antagonistic trend in ranking the years starting in 1995, when dab was first, sprat was second and plaice was fourth in abundance. In the cold winter of 1996 the winter-spawning plaice ranked first, dab second and sprat was last, together with sole, Solea solea (there was only one sprat egg during the 1996 survey). The effect of the cold winter of 1996 seemed to be long lasting for sprat, as it took this species 4 years (until 2000) to regain the second position in the ranking of numerical abundance in the southern North Sea ecosystem. At the same time, plaice permanently became less well represented in the February/March samples and took fifth position in 2000 (Fig. 2). The same feature was also apparent in the ranking of flounder, cod and whiting egg occurrence since 1995 (Fig. 2). 
Another species which showed a trend towards increasing abundance, particularly after 1995, and hence improved its ranking during the period of observation, was rockling (Onos spp.). Although it was also heavily affected by the cold winter 1995/96, abundance increased steadily thereafter, until in 1999 rockling eggs were the second in abundance after dab.

Despite apparent differences in ranking, correlation between species ranks was generally high (Spearman $>0.7$; Kendall >+0.5) and revealed only gradual differences between years, indicating a rather high similarity of species assemblages in the overall area.

As expected, true 'summer species' such as mackerel (Scomber scombrus) and gurnard (Eutrigla gurnardus) did not occur in the spring samples.

\section{Species diversity}

Although species number in winter tended to be higher during periods of high temperature, this was not necessarily reflected in the Shannon index of diversity as exemplified in 1995 and 1999 (Table 1: 1.2; 0.96). Diversity was higher in 1991 and $1996\left(H^{\prime}=1.42 ; 1.41\right)$ due to a balanced representation of the other important spring/winter spawners such as cod (Gadus morhua), whiting (Merlangius merlangus), flounder (Pleuronectes flesus) and plaice (Pleuronectes platessa). During most other years of high species richness $(1992,1993,1995$, 1998, 1999, 2000), however, the species assemblage was dominated by dab (Limanda limanda), thus yielding a rather low Shannon Index $H^{\prime}$, but a high dominance index (Berger-Parker Index) of $>0.6$ as shown for area I and the overall area in Table 1. In 1993 the Shannon Index fell to 0.72 (area I and II, $H^{\prime}=0.59 ; 0.45$ ) although species number was 11. Despite an increase in species number to 15 in 1999, the species assemblage continued to be dominated by dab, which is reflected in the rather high dominance value (Berger-Parker Index) of 0.78 (Table 1$)$ and the relatively low diversity $\left(H^{\prime}=0.96\right)$.

As can be seen from Table 1, species diversity (Shannon) was generally higher during the summer surveys at high SST between $15^{\circ} \mathrm{C}$ and $17^{\circ} \mathrm{C}\left(H^{\prime}>2.0\right.$ in $1987 ; 1991)$ as compared to the winter/spring species assemblage. This was caused not only by the higher species number but also by the balanced occurrence of species in the warm-water-dominated species assemblage (see also low index of dominance in Table 1). Within the winter/spring assemblages between mean SST measurements (Helgoland Roads) of $0.75^{\circ} \mathrm{C}(1996)$ and $5.25^{\circ} \mathrm{C}$ (1995) there was no temperature effect on the species diversity index $H^{\prime}$ (Fig. 2) in the sense that, with increasing temperature, species diversity would increase. The occasional occurrence of 'warm water' species in the winter assemblages did not exert any impact on community structure because of their numerical insignificance and the dominance of only a few (at times only one) species. The high Berger-Parker Index (1993; 0.83; Table 1) for all years except 1986, 1991 and 1996, years that were notable for low SSTs, may be an indication of the two different types of assemblages present in the winter/spring surveys. While an increase in temperature over the whole area of investigation gave rise to a species assemblage with higher diversity (i.e. a summer assemblage), an increase in temperature or a wide range of temperature within an established winter assemblage did not produce higher diversity even though the occasional rare southern species occurred (Fig. 2).

Due to the large sample sizes, inter-annual variances between the Shannon Indices of the overall area were small, and therefore differences in Shannon Indices, unlike those in ranking, were highly significant $(P<0.001$, after Hutcheson 1970) for almost all years. Exceptions were the winter assemblages of 1986/2000, 1986/1995 and 1995/2000 with a Shannon Index of 1.22/1.21, $1.22 / 1.2,1.2 / 1.21$ and 1991/1996 with indices between 1.42 and 1.41 , respectively (Table 1 ).

\section{Species abundance models}

In no area were all species equally common, given that the preponderance of coastal and more seaward stations varied, due to different sampling coverage caused by varying weather conditions. However, a common feature for all years was a $\log$ distribution of the occurrence pattern, that is, a few (sometimes only one) species were very abundant (in spring always dab with the exception of 1996), while a large proportion would comprise only a few individuals. The small number of abundant species and the large proportion of 'rare' species predicted by the log series model suggest that it will be most applicable in situations where one or a few factors dominate the ecology of a community (Magurran 1988).

When testing the existing species distribution for the overall area on a hypothetical log distribution, we found that all years between 1986 and 2000 fitted a log-normal distribution reasonably well ( $\chi^{2}$ test, $P>0.05$ ).

\section{Discussion}

\section{Designation of areas}

For the interpretation and distinctness of phenomena, choice and delineation of a sub-area are crucial, since sub-areas differ significantly in temperature and salinity. Both are known to affect the spawning behaviour of adult fish and, in addition, have relevance to development, hatching success and vertical distribution of fish eggs (Westernhagen 1970). It is therefore likely that the occurrence of species in the samples was influenced by the hydrography. At the same time the hydrography also influences the catchability of pelagic eggs (at low salinity, eggs sink in the water column and may escape the net which is towed at the surface). The combination of low temperature and low salinity, for instance, makes area I less suited for boreal species such as cod, whiting, long 
rough dab and possibly also Onos spp. (see Aurich 1940), but also for the Atlantic species.

On the other hand, egg distribution over the total area was sufficiently uniform to allow an overall evaluation of all three sub-areas for individual species. For this reason a generalisation of findings typically refers to the whole southern North Sea rather than to the individual sub-areas.

\section{Classification of species}

What are the species that are termed 'typical spring spawners' for the southern North Sea? Ehrenbaum and Mielck (1910), in their classical treatise on the North Sea winter spawning fish, listed only the seven species (plaice, flounder, dab, long rough dab, cod, whiting and rockling) occurring commonly and three rarely occurring species (i.e. sprat, gurnard, sole). Aurich (1940), in his detailed compilation of the distribution of pelagic fish eggs and larvae in the southern North Sea, grouped the fish that spawn in the southern North Sea into four classes: namely (1) Arctic-boreal (and boreal-endemic), (2) Mediterranean/Atlantic-boreal, (3) Mediterraneanboreal, and (4) Mediterranean-Atlantic/boreal. These classifications (following Ekman 1935) mainly took account of the spawning temperature in the respective species. The listed southern North Sea spawners included under category (3) (Mediterranean-boreal with optimum spawning temperatures between $6-16^{\circ} \mathrm{C}$ ) are predominantly (seven out of nine) species that we encountered also in our winter egg surveys, when low water temperatures prevailed - but usually in the last ranks behind the Arctic-boreal species. The only occasion when a member of the Mediterranean-boreal realm ranked high in abundance was the distribution of sprat (Clupea sprattus) in the spring surveys during the years which were particularly warm, i.e. 1995, 1998, 1999 and 2000.

For a direct comparison of species distribution, the data of Aurich (1940) are the most suitable. The areas of sampling for the two series are practically identical, and the sampling time extending from winter (February) until early summer (June), covered the period of our own surveys, i.e. February/March. The information on the North Sea spawning fish provided by Ehrenbaum (1905-1909) are based on too large an area for this purpose (total number of species with pelagic eggs is 76). A comparison between the species caught by Aurich (1940) between 1926 and 1937 and the present series from 1984 until 2000 displays a high degree of concurrence in terms of species present. We found only six species on top of the species assemblage described by Aurich (1940). All six fall into the category of the 'Mediterranean-boreal' or 'Lusitanian' realm, as defined by Aurich (1940) and Wheeler (1978).

The same trend towards an increased occurrence of 'Lusitanian' species has been reported for the International Bottom Trawl Survey (Heessen 1996) and the study of English inshore demersal fish populations
(Rogers and Millner 1996) and has been attributed to the relatively warm winters after 1990 .

\section{Relation between egg abundance and 'stock biomass'}

Although as marine biologists we are aware of the fact that no correlation exists between egg abundance and the number of recruits for the respective year, one must accept that without eggs there will be no recruitment. The latter statement is responsible for the use of the term 'recruitment overfishing', which refers to the situation that once only extremely few eggs are available for the production of recruits this will invariably have an effect on recruitment. At present this situation might have occurred in the southern North Sea in some species, and it is for this reason that we consider our data in the light of developments in fish stock biomass (or populations) in the southern North Sea.

From Fig. 2 it can been seen that for some species a trend in changes of abundance is occurring. This is particularly true for the most common species, i.e. those targeted by the fishery. It is for these species that figures on egg abundance are the most reliable, as the relevant findings are based on relatively large numbers of eggs. Since the egg surveys provided only a relative measure of abundance, given that no exact record of the filtered water mass was kept, we calculated the abundance of the spring spawners in relation to dab eggs (dab having the value 1.0) which were usually the most common ones in the samples. Thus an indirect comparison of the change in spawning stock biomass of the spring spawners relative to dab over the period of 1984-2000 is available and is displayed in Fig. 3.

\section{$D a b$ (Limanda limanda)}

Dab eggs were the most common eggs collected throughout the study (except for 1996), which reflects the high abundance of this species in the southern North Sea ever since the time of Schnakenbeck (1928). This situation remained unchanged until now; in fact the abundance of dab since 1973 has permanently increased and probably tripled between 1985 and 2000 (see Heessen and Daan 1996).

Only in 1996 were plaice eggs the most abundant. This has to be seen in light of the changing environmental conditions when water temperatures were extremely low, favouring the spawning of plaice and hampering the warm-water adapted dab (Schnakenbeck 1928). As was the case for rockling (Onos spp.) dab abundance in the North sea is positively correlated with beamtrawl effort, a fact which Heessen and Daan (1996) discussed as a possible common feature that favours species which mature at a relatively small size compared with most commercial species. Other species belonging into this group are gurnard (a summer spawner) and long rough dab (Hippoglossoides platessoides). Although the latter 
Fig. 3 Numerical importance as percentage distribution of pelagic fish eggs in the southern North Sea calculated against the number of dab (Limanda limanda) eggs which were given the value 1.0 in each year. Lower figure: Mean SST $\left({ }^{\circ} \mathrm{C}\right)$ in February/March at Helgoland Roads. Solid line indicates mean temperature at cruise stations. Abbreviations as in Fig. 2.
Numbers of different fish species in relation to number of dab (area: total / season: wi)

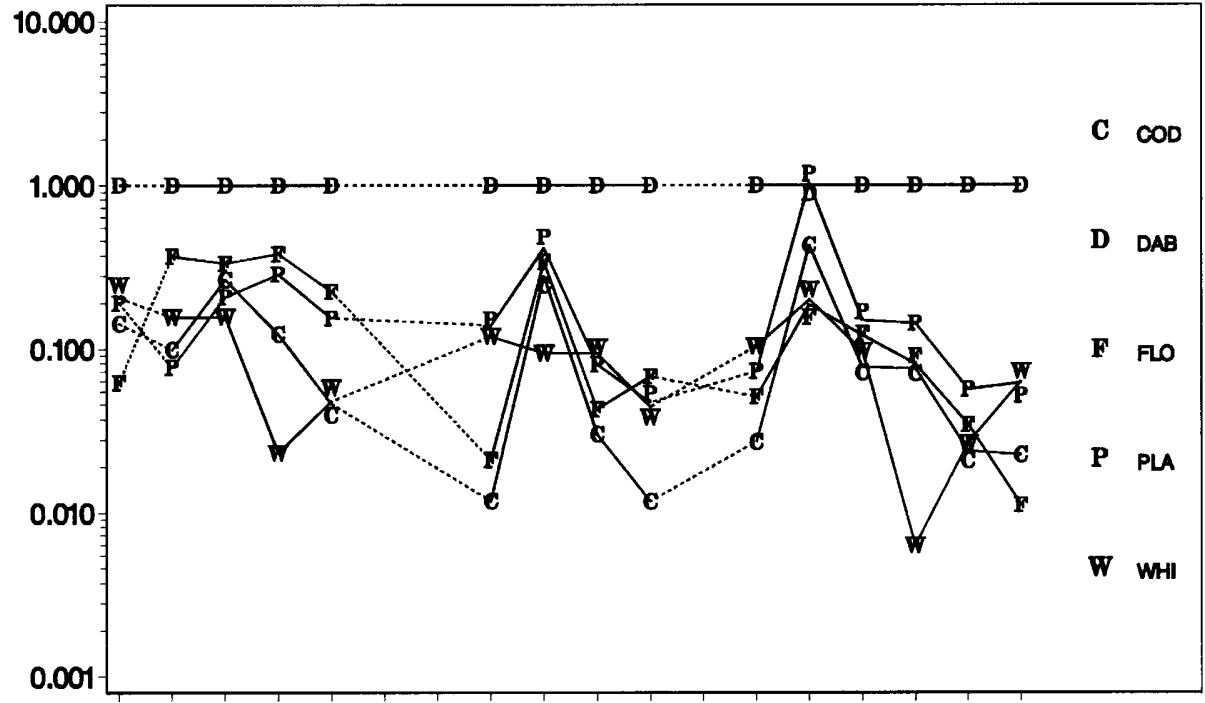

$\begin{array}{llllllllllllllllll}08 & 84 & 85 & 86 & 87 & 88 & 89 & 90 & 91 & 92 & 93 & 94 & 95 & 96 & 97 & 98 & 99 & 00\end{array}$

\section{a}

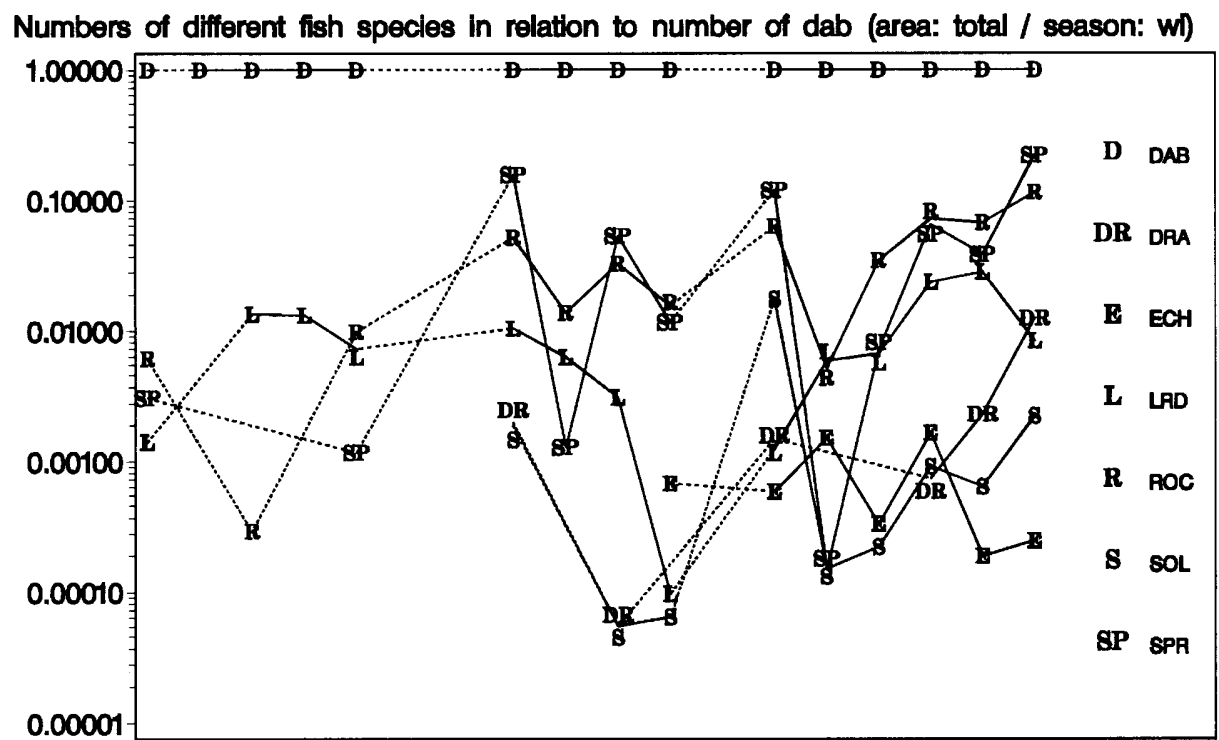

$\begin{array}{llllllllllllllllll}08 & 84 & 85 & 86 & 87 & 88 & 89 & 90 & 91 & 92 & 93 & 94 & 95 & 96 & 97 & 98 & 99 & 00\end{array}$

b

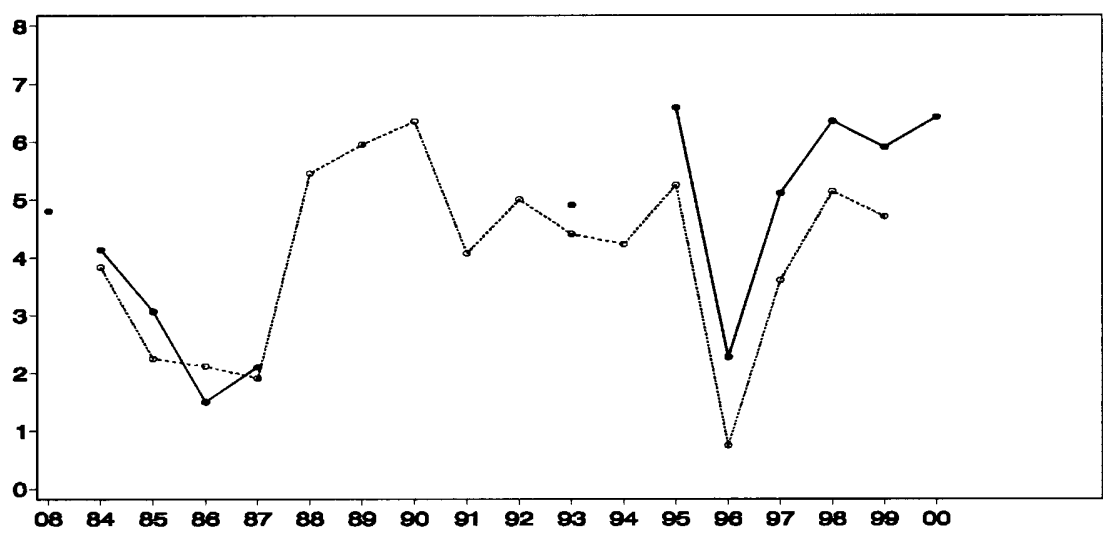


Table 3 Correlation between temperature and abundance of species in catches of pelagic fish eggs in the southern North Sea 1984-2000. Abundance data for fish eggs normalised against number of dab eggs caught in the respective years

\begin{tabular}{llllllllll}
\hline Whiting & Flounder & Cod & Plaice & Rockling & Lesser weever & Sprat & Sole & Long rough dab & Dragonet \\
\hline-0.3019 & -0.6858 & -0.6487 & -0.6487 & 0.7855 & -0.16855 & 0.7703 & 0.3262 & 0.0976 & 0.6218 \\
n.s. & $P<0.01$ & $P<0.01$ & $P<0.01$ & $P<0.01$ & n.s. & $P<0.01$ & n.s. & ns & $P<0.01$ \\
\hline
\end{tabular}

was not particularly well presented throughout the area, it increased as well in area II.

Plaice (Pleuronectes platessa) and flounder (Pleuronectes flesus)

A remarkable and consistent development was noticeable for plaice eggs. In 1991 and 1992 plaice eggs ranked second and third in abundance and became first in 1996 (Fig. 2). The latest development indicated a clear drop in the abundance of plaice eggs (Fig. 3). This is consistent with the trends in population development for this species as documented by Rijnsdorp and Millner (1996), who found a considerable decrease in catch per unit effort leading to a historical low of the spawning stock biomass in North Sea plaice. This trend still persists (Serchuk et al. 1996). Nevertheless, the importance of plaice eggs in spring remained relatively high when viewed against dab eggs (Fig. 3), indicating that the observed decline in ranking is also caused by a change in the temperature regime and the occasional invasion of other species rather than by a decline in the spawning stock biomass of plaice.

In flounder, the development of egg abundance after 1995 saw a maximum in 1997 and 1998 but declined thereafter as observed in plaice. Since both species have similar requirements regarding temperature, the external factor responsible for this development may have been the same, although flounder eggs became very scarce after 1999 (Fig. 3). No data are available as to the development of the flounder stocks in the North Sea, but since in coastal areas flounder are caught together with plaice, stock development may very well be similar to that of plaice.

\section{Sole (Solea solea)}

The fact that sole eggs occurred more and more regularly in the spring surveys is largely independent of their numerical occurrence. It probably reflects the temperature effect which is visible in species that have their geographical limit of spawning (and distribution) in the area of the southern North Sea. Sole eggs at the same time exhibited a marked increase in ranking starting in 1995 which, when viewed against the occurrence of dab eggs, reflects an increase in relative abundance (Fig. 3). The loss in ranking is thought to reflect the advent of 'new' species in the species list, as illustrated in Fig. 2. However, due to the fact that sole is not a typical spring spawner and the present records of egg occurrence just mark the beginning of the spawning season, generalisations regarding total spawning biomass have to be made with caution. This is particularly so since the total numbers of eggs found on each cruise were rather low.

\section{Gadids (Gadus morhua, Merlangius merlangus)}

The development of the egg abundance of both species (cod and whiting) gives reason for concern when viewed against their importance in the species assemblage. In fact both trends (starting in 1984) are indicative of the declining role these gadids play in the southern North Sea ecosystem, a development which is mirrored by the recent development of the cod and gadoid biomass in the southern North Sea (Pope and Macer 1996; Heessen and Daan 1996).

As can be seen in Figs. 2 and 3, the declining abundance of gadoid eggs during the 1990s is at the same time positively correlated with the rising temperature. This again suggests that the rise in temperature during the recent past may have contributed to the decline in gadoid stocks, given that the gadoids in the North Sea are at their southern range of distribution.

\section{Sprat (Sprattus sprattus) and rockling (Onos spp.)}

Sprat and rockling eggs have become more abundant in the late 1990s. Sprat is a species whose egg abundance was quite clearly influenced by temperature. Its abundance was positively correlated with temperature (Table 3), the most striking effect being the change in the mid-1990s, when sprat eggs almost disappeared from the plankton (1996) to the extent that the spring presence of sprat only slowly recovered in the North Sea over the following years (Fig. 3). While this development in sprat is apparently a result of the positive temperature development after 1996, the same trend for rockling may have had other causes, probably relating to increased fishing pressure.

Species richness, abundance and assemblage

The majority of fish communities display a log-normal pattern of species abundance (Sugihara 1980), which is typical for a large, mature and varied natural community. However, in the present study the species distribution pattern resembled that of a log distribution, which is 
indicative of a system controlled by one or only a few external factors. The question why, in this case, an apparently large and varied ecosystem, the North Sea, does not follow the general rule may be explained by the fact that only a fraction of the whole system (the pelagic winter spawners) have been considered in the model. This limitation then reduced the species number considered in the model and may have led to a faulty perception. In fact, in some of the years species distribution would have also been adequately described by a log-normal distribution. But this was not consistent and the year with the largest species number (1999) was significantly different from a log-normal model.

The alternative explanation for a log distribution may be the overriding influence of temperature in species distribution and assemblage of pelagic fish eggs in the southern North Sea as it is evident from the positive correlation between species abundance and temperature (Table 3), and the above mentioned differences in species composition between winter and summer assemblages.

In fact, the significant negative correlation with temperature in the occurrence of eggs of flounder, cod and plaice are just a confirmation of this very strong influence of temperature, which works likewise in the other direction, i.e. a positive correlation between temperature and the occurrence of sprat, rockling and dragonet eggs. Although sole egg abundance did show a positive correlation with temperature (see Table 3) this was not significant, nor was the negative correlation significant for the occurrence of whiting eggs.

When comparing the number of species recorded during the recent work with data available from Ehrenbaum (1905-1909) and, for the period between 1925 and 1937 from Aurich (1940), we notice a general agreement with Ehrenbaum (1905-1909), who compiled the species list on the basis of the available literature. Of the 76 northern fish species known to spawn pelagic eggs he listed 34 'species' occurring in the North Sea proper. This figure included some species that have only a local distribution (i.e. Ctenolabrus rupestris), are easily confounded with other species (Gadus minutus vs. Pleuronectes flesus) and may thus have been overlooked, or can only be identified with certainty to the genus (i.e. including two species under one taxonomic classification, i.e. Onos spp.). While we have defined 26 taxa, Aurich (1940) found only 19 species in his investigations on the distribution of pelagic fish eggs and larvae in the southern North Sea in the period 1926-1937. In our investigations we were able to confirm the presence of all species mentioned by the latter author except for Ctenolabrus rupestris. Additional species recorded by us between 1986 and 2000 were Argentina silus, Arnoglossus laterna, Clupea pilchardus, Echiichthys vipera, Pollachius virens, Mullus surmuletus, Phrynorhombus norwegicus, Solea solea, Zeus faber and an unidentified species in 1991 and 1992. These species during the present study were either only detected during the summer cruises (P. norvegicus, $C$. pilchardus, and the unidentified species) since they belong to the 'summer spawners' or are but sporadically represented. Only sole (Solea solea) and dragonet (Callionymus lyra) started to occur regularly (although in moderate numbers) in the February/March samples from 1992 and 1995 onward, respectively, indicating a gradual change in the winter/spring species assemblage. This change, though, was only remarkable through the sporadic occurrence of southern species in the North Sea but did not fundamentally affect the species assemblage and was not reflected in a change in species diversity (Shannon index) or a change in dominance.

A comparison using the Bray-Curtis coefficient for dissimilarity between the cold $(1986,1987,1991,1996)$ and the warm or normal winter/spring assemblages likewise did not reveal any substantial changes in species assemblage, indicating no permanent shift towards a preponderance of more southerly species.

In fact, a comparison of ecological population parameters between 1986 and 2000 with data derived from egg surveys in February/March 1908 (Ehrenbaum and Mielck 1910) in the southern North Sea showed a pronounced similarity in species occurrence. When applying the same approach as used in Fig. 3 to 1908 data, dab eggs were the most important species (1.0) followed by whiting (0.2), plaice (0.19), cod (0.14), flounder (0.06) and rockling (0.006). Sprat, long rough dab and gurnard were only sporadically represented in 1908 . While the species assemblage was very close to that determined for 1985, 1986 and 1987, ranking and relative abundance of the respective species have changed when compared to records from the 1990s (Fig. 3; see 2000). Thus, in agreement with the findings of Heessen and Daan (1996), in today's North Sea ecosystem the species that reproduce at a small size such as dab, sprat, long rough dab and rockling have attained a greater importance than they had at the beginning of the twentieth century or even in the 1980s (Fig. 3). This fact is directly reflected in the development of the egg abundance of the respective species. Commercial species, particularly gadids, which for 100 years were under considerable fishing pressure, have become scarce - and so have their eggs as a consequence of the decline in spawning stock biomass.

While the occasional occurrence of 'Lusitanian' fish species has been frequently documented (Aurich 1953; Corten 1990; Boddeke and Vingerhoed 1996; Scheffel et al. 1996), this phenomenon has not significantly influenced the typical pelagic fish egg assemblage of the southern North Sea when considering the common community parameters. Although the presence of more 'Lusitanian' species may be regarded as an early indication of changes, the present southern North Sea ecosystem is still far from being strongly influenced by these taxa. At present there is no discernible trend for southern species towards a major invasion into, or an installation in, the North Sea ecosystem. 


\section{References}

Aurich HJ (1940) Die Verbreitung der pelagischen Fischbrut in der südlichen Nordsee während der Frühjahrsfahrten 1926-1937 der deutschen Forschungsschiffe "Poseidon" und "Makrele". Helgol Wiss Meeresunters 2:183-225

Aurich HJ (1953) Verbreitung und Laichverhältnisse von Sardelle und Sardine in der südöstlichen Nordsee und ihre Veränderungen als Folge der Klimaänderung. Helgol Wiss Meresunters 4: 175-204

Berg S, Krog C, Muus B, Nielsen J, Fricke R, Berghahn R, Neudecker T, Wolff WJ (1996) IX. Red list of lampreys and marine fishes of the Wadden Sea. Helgol Meeresunters 50[Suppl]:101-105

Boddeke R, Vingerhoed B (1996) The anchovy returns to the Wadden Sea. ICES J Mar Sci 53:1003-1007

Corten A (1990) Long-term trends in pelagic fish stocks of the North Sea and adjacent waters and their possible connection to hydrographic changes. Neth J Sea Res 25:227-235

Cushing DH, Dickson RR (1976) The biological response in the sea to climate changes. Adv Mar Biol 14:1-122

Dethlefsen V, Westernhagen H von, Cameron P (1996) Malformations in North Sea pelagic fish embryos during the period 1984-1995. ICES J Mar Sci 53:1024-1035

Dörjes J (1986) Langfristige Entwicklungstendenzen des Makrozoobenthos der Deutschen Bucht. Data submitted by the Federal Republic of Germany to the Scientific and Technical Working Group, International North Sea Conference, 1987

Ehrenbaum E (1905-1909) Eier und Larven von Fischen des Nordischen Planktons. Lipsius und Fischer, Kiel

Ehrenbaum E, Mielck W (1910) Eier und Larven der im Winter laichenden Fische der Nordsee, Fangtabellen. Helgol Wiss Meeresunters 9:174-176

Ekman S (1935) Tiergeographie des Meeres. Akademische Verlagsgesellschaft, Leipzig

Fransz HG, Colebrook IM, Gamble JC, Krause M (1991) The zooplankton in the North Sea. Neth J Sea Res 28:1-52

Heessen HJL (1996) Time-series data for a selection of forty fish species caught during the International Bottom Trawl Survey. ICES J Mar Sci 53:1079-1084

Heessen HJL, Daan N (1996) Long term changes in ten non-target North Sea fishes. ICES J Mar Sci 53:1063-1078

Hickel W, Böse A, Radach G (1986) Stickstoff-Mengen und Phytoplankton-Bestände in der Deutschen Bucht im Hinblick auf das Eutrophierungsproblem. Ber Biol Anst Helgol 1:1-46

Hurlbert SH (1971) The non-concept of species diversity: a critique and alternative parameters. Ecology 52:577-586

Hutcheson K (1970) A test for comparing diversities based on the Shannon formula. J Theor Biol 29:151-154

Krebs CJ (1999) Ecological methodology, 2nd edn. Addison Wesley, Menlo Park, Calif.

Kröncke I (1992) Macrofauna standing stock of the Dogger Bank. A comparison: 1950-54 versus 1985-87. A final summary. Helgol Meeresunters 46:137-169

Lozán JL (1990) Zur Gefährdung der Fischfauna - Das Beispiel der diadromen Fischarten und Bemerkungen über andere Spezies. In: Lozán JL, Lenz W, Rachor E, Watermann B, Westernhagen $\mathrm{H}$ von (eds) Warnsignale aus der Nordsee. Parey, Berlin, pp 231-249
Magurran AE (1988) Ecological diversity and its measurement. Croom Helm, London

Margalef R (1972) Homage to Evelyn Hutchinson, or why is there an upper limit to diversity. Trans Conn Acad Arts Sci 44: 211-235

Norse EA (ed) (1993) Global marine biological diversity: a strategy for building conservation into decision making. Island Press, Washington, D.C. pp 14-37

Pielou EC (1966) Shannon's formula as a measurement of specific diversity: its use and disuse. Am Nat 100:463-465

Pielou EC (1975) Ecological diversity. Wiley, New York

Pope JG, Macer CT (1996) An evaluation of the stock structure of North Sea cod, haddock, and whiting since 1920, together with a consideration of the impacts of fisheries and predation effects on their biomass and recruitment. ICES J Mar Sci 53: $1157-1169$

Preston FW (1948) The commonness, and rarity, of species. Ecology 29:254-283

Radach G, Bohle-Carbonell M (1990) Strukturuntersuchungen der meteorologischen, hydrographischen, Nährstoff- und PlanktonLangzeitreihen in der Deutschen Bucht bei Helgoland. Ber Biol Anst Helgol 7:1-425

Rijnsdorp AD, Millner RS (1996) Trends in population dynamics and exploitation of North Sea plaice (Pleuronectes platessa L.) since the late 1800s. ICES J Mar Sci 53:1170-1184

Rogers SI, Millner RS (1996) Factors affecting the annual abundance and regional distribution of English inshore demersal fish populations: 1973 to 1995. ICES J Mar Sci 53:1094-1112

Scheffel HL, Marciniak M, Schirmer M (1996) Larven der dünnlippigen Meereäsche Liza ramada (Mugilidae) in der Weser - Anzeichen einer Klimaveränderung? Abh Naturwiss Ver Bremen 43:599-607

Schnakenbeck W (1928) Teleostei Physoclisti 10. Heterosomata. In: Grimpe G, Wagler E (eds) Die Tierwelt der Nord- und Ostsee. Akademische Verlagsgesellschaft, Leipzig, pp 1-60

Serchuk FM, Kirkegaard E, Daan N (1996) Status and trends of the major roundfish, flatfish, and pelagic fish stocks in the North Sea: thirty-years overview. ICES J Mar Sci 53:1130-1145

Southward AJ (1963) The distribution of some plankton animals in the English Channel and approaches. III. Theories about long-term biological changes, including fish. J Mar Biol Assoc UK 43:1-29

Sugihara G (1980) Minimal community structure: an explanation of species abundance patterns. Am Nat 116:770-787

Tiews K (1990) 35-Jahres-Trend (1954-1988) der Häufigkeit von 25 Fisch- und Krebstierbeständen an der deutschen Nordseeküste. Arch Fischereiwiss 40:39-48

UNEP (1995) United Nations Environment Programme. Global biodiversity assessment. Cambridge University Press, Cambridge

Vermeij G (1993) Biogeography of recently extinct marine species: implications for conservation. Conserv Biol 7:393-413

Westernhagen H von (1970) Erbrütung der Eier von Dorsch (Gadus morhua), Flunder (Pleuronectes flesus) und Scholle (Pleuronectes platessa) unter kombinierten Temperaturund Salgehaltsbedingungen. Helgol Wiss Meeresunters 21: 21-102

Wheeler A (1978) Key to the fishes of northern Europe. Frederick Warne, London

Winston J (1992) Systematics and marine conservation. In: Eldredge N (ed) Systematics, ecology, and the biodiversity crisis. Columbia University Press, New York 